\title{
The European Network condemns any restriction to the European Convention on Human Rights
}

The European Network of Rehabilitation Centres for Survivors of Torture was founded in 2003 and is a professional network of doctors, psychologists, psychotherapists, social workers and lawyers from over 100 organisations and rehabilitation centres in Europe that provide specialist rehabilitation to survivors of torture and other human rights violations, either asylum seekers and refugees in host countries or victims of past or current regimes. *

\section{The European Network condemns any restriction to the European Convention on Human Rights}

The European Network of Rehabilitation Centres for Survivors of Torture ('the European Network') welcomes Denmark's determination to combat torture, but criticises any proposal to restrict the European Court of Human Rights in its ability to interpret the European Convention on Human Rights and Fundamental Freedoms ('the Convention') in respect of family reunion, as suggested by the Danish Minister for Immigration and Integration. Proposals to limit such rights to citizens of the 47 countries which

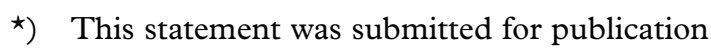
by committee members Elise Bittenbinder, Nimisha Patel and Camelia Doru on behalf of the European Network of Rehabilitation Centres for Survivors or Torture.

Correspondence to: cameliadoru@icarfoundation.ro make up the Council of Europe, and to withdraw them from citizens of other countries, will severely restrict refugees' opportunities for family reunification. ${ }^{1}$

On 15 November 2017, Denmark took the chairmanship of the Committee of Ministers of the Council of Europe. The European Network welcomes Denmark's stated aim that "The Council of Europe must continue to combat torture ... the Danish chairmanship will ... make sure that the fight against torture is strengthened."

However, Denmark has also announced plans to continue the programme of reform of the European Court of Human Rights. The European Network is concerned at reports that the Danish Minister for

1 For additional background see http://refugees.dk/ en/news/2017/may/danish-chairmanship-of-thecouncil-of-europe-to-weaken-human-rights/ 
Immigration and Integration, Inger Støjberg, has suggested that these plans would lead to the restriction of the right to family reunification, while it would no longer be a right for refugees - and thus for victims of torture among them-under Article 8 of the Convention.

The European Network strongly opposes any measure that will result in denying any refugee the possibility of living together with their family. Evidence clearly demonstrates that victims of trauma and torture depend on their family for sustained rehabilitation and integration in the recipient country. State signatories to the UN Convention Against Torture (UNCAT), which includes the 47 member states of the Council of Europe, are required by article 14 of that Convention to "ensure in its legal system that the victim of an act of torture obtains redress and has an enforceable right to fair and adequate compensation, including the means for as full rehabilitation as possible."

General Comment No. 3 of the Committee against Torture on the implementation of article 14 by States parties makes clear that the term "victim" also includes affected immediate family or dependants of the victim.

The European Network considers that the absence of immediate family and/or dependents has real and direct implications for and is detrimental to the successful recovery - both physical and psychological—for traumatised asylum seekers and torture survivors.

The risk of developing additional severe and enduring health problems is very high for those without their family and relatives particularly since the absence of family also weakens the torture survivor's social networks which further impedes their sustained recovery.

The European Network therefore strongly disagrees with any proposals to restrict refugees' access to family re-unification as this is likely to have devastating and irreversible health consequences to those torture survivors affected. 
Exploring the connections between the Danish Chairmanship of the Council of Europe, torture survivors, and rehabilitation centres

\section{Jacques Hartmann*}

As the statement by the European Network of Rehabilitation Centres for Survivors of Torture details, in November 2017 Denmark took over the rotating chairmanship of the Council of Europe. The Council - an international organisation aiming to uphold human rights, democracy, and the rule of law in Europe - was established in 1949. Today, it has 47 members states, including all members of the EU. It works by agreeing international legal standards in a wide range of areas, but is best known for the adoption of the European Convention on Human Rights. Denmark is a founding member of the Council and a founding party of the Convention and has traditionally been a strong supporter of human rights. Yet initially the Danish Government's chief priority during the six-month long chairmanship was reform of the Convention system. Whilst the cut and thrust of politics means there is now less focus on reform, there remains a strong anti-human rights sentiment in Denmark, reflecting a populist challenge that has engulfed not just Denmark but the entire world. ${ }^{1}$

\section{Why does Denmark want reform?}

Immigration has long been a dominant theme in Danish politics. In the late 1990s, the Danish People's Party (DPP) began to denounce immigration, multiculturalism and Islam as alien to Danish society and values. Since 2001, the DPP has supported various minority coalition governments and gained extensive influence on Denmark's immigration policy, which is now one of the most restrictive in Europe.

Critique of the Convention system is not new in Denmark, where much debate has focused on Article $8,{ }^{2}$ which includes a right to respect for family life. This right is especially controversial when it affects immigration policy, such as family re-unification or the deportation of foreign criminals.

In May 2016, the Danish Supreme Court delivered a judgment which reignited the debate, by preventing the deportation of a notorious convicted criminal and Croatian national, Gimi Levakovic. Despite Levakovic's egregious criminal record, the Danish Supreme Court found that his deportation would constitute a disproportionate interference with his right to respect for family life.

The decision started a maelstrom. ${ }^{3}$ Public outrage was fuelled by the fact that Levakovic was a household name, after

1 P. Alston, The Populist Challenge to Human Rights, fournal of Human Rights Practice (2017) $1-15$.

2 Article 8(1) sets out,'Everyone has the right to respect for his private and family life, his home and his correspondence.'

3 The debate in Denmark is in many ways reminiscent of the debate in the UK in the early 2000s. See C. Geart, On Fantasy Island (OUP, 2016). 
he had appeared on a 2015 Danish TV documentary. Politicians across the political spectrum have since called for reform of the Convention system. The current minority centre-right coalition, consisting of three parties and supported by the DPP, works on the basis of a political agreement adopted in November 2016, which expresses the need to 'critically review' the European Court of Human Rights' dynamic interpretation.

\section{Is there a need for further reform?}

The Convention system has already been reformed. From 2010-2015 four high-level conferences were convened to identify means to guarantee the long-term effectiveness of the Convention system. ${ }^{4}$ This led to the adoption of two amendment protocols. Protocol 15 which, among other things, will introduce a reference to the 'principle of subsidiarity', according to which the primary responsibility for implementing and enforcing the Convention lies with national authorities; and Protocol 16 which will allow the highest domestic courts to request advisory opinions from the the European Court of Human Rights. So far, however, neither of the two protocols have recieved ratifications to enter into force. Denmark, moreover, has no intention of ratifying Protocol 16. Despite this lack of progress, a comprehensive two-year expert review of the reform process highlighted positive results and concluded in 2015 that there was no need for 'major reform'. ${ }^{5}$

4 Interlaken (2010), Izmir (2011), Brighton (2012) and Brussels (2015).

5 The longer-term future of the system of the $\mathrm{Eu}-$ ropean Convention on Human Rights, Report of the Steering Committee for Human Rights (11 December 2015) 11.

\section{What reforms are envisaged by Denmark?}

The objective of the Danish chairmanship remains somewhat unclear. This is partly due to the fact that many Danish politicians seem to be in a competition to express the most discontent with the current human rights system, which means that it is not always easy to distinguish hyperbole from policy statements. The chairmanship, however, focuses on five themes, including 'Combating torture' and the ambiguous theme, the 'European human rights system in a future Europe'. ${ }^{6}$ The first theme will lead the Danish chairmanship to focus on the fight against torture, which will include a seminar in March 2018. The seminar will focus on combating torture in the early stages of police custody and pre-trial detention. The second theme included a high-level expert conference, which took place from 22-24 November 2017. In a subsequent conference report, the Danish Government writes that previous reforms of the Convetion system have brought 'notable progress', such as strengthening the principle of subsidiarity, improving the efficiency of the European Court of Human Rights and addressing the need for more effective implementation of its judgments. ${ }^{7}$ Despite the progress, the report states that the 'Danish Chairmanship wishes to ensure that the measures already adopted are effectively

6 'Europe in a time of unrest and upheaval-strong values and a future-proof Council of Europe', The Danish Chairmanship of the Committee of Ministers of the Council of Europe (November 2017 to May 2018). Available at: <www.coe.int/ en/web/chairmanship>.

7 Conference report High-Level Expert Conference 2019 and Beyond: Taking Stock and Moving Forward from the Interlaken Process. Available at: <www.ft.dk/samling/20171/almdel/REU/ bilag/118/1838949/index.htm> 
implemented, including through the entering into force of Protocol 15, ${ }^{8}$ A further priority is 'enhanced dialogue' between member states and the Court.

\subsection{Enhanced Dialogue}

The Danish Minister of Justice has stated that criticism of the Convention system in countries like Denmark to a large degree stem from feelings of detachment. He said: 'Populations and decision-makers feel they are not being involved and listened to'. ${ }^{9}$ In Denmark, critique has, in addition to the deportation of foreign criminals, focused on the European Court of Human Rights' dynamic interpretation. Dynamic interpretation means that standards in the Convention are not static, but rather interpreted in light of social changes by the Court. In this regard, it has been criticised for interpreting rights into the Convention that the drafters never intended to include. Despite not being contrary to international law, the Minister of Justice has explained that the Government will use its chairmanship to focus on the European Court of Human Rights' dynamic interpretation, which he thinks has gone too far. ${ }^{10}$

The aim of the enhanced dialogue is to establish better means to influence the Court. ${ }^{11}$ It is not, however, clear how this could be done without also undermining its impartiality. Dialogue is important.

Conference report (n 7) 3.

9 Ibid., 4.

10 Overrasket justitsminister vil tage dommer på ordet og blande sig i kontroversielle sager, Politiken (28 August 2017).

11 See comments made by the Danish Prime Minister at a press conference on 3 November 2017. Availble at <www.regeringen.dk/nyheder/danmark-overtager-formandsskabet-for-europaraadets-ministerkomit $\% \mathrm{C} 3 \% \mathrm{~A} 9 />$.
The former President of the Court, Dean Spielmann, described judicial dialogue as the 'golden key' to a desirable future for the protection of human rights in Europe. ${ }^{12}$ Yet, dialogue already exists. As noted by the current President, Guido Raimondi, one of the most salient features of the reform process, which started in 2010, has been an intensification of the dialogue with national courts. ${ }^{13}$ States can also influence the Court's interpretation by intervening in ongoing cases. Yet, Denmark has only done so once. ${ }^{14} \mathrm{~A}$ futher possibility for influencing the Convention system is envisaged in Protocol 16, which, when it enters into force, will allow for advisory opinions. ${ }^{15}$

\section{What will be the outcome of the Danish Chairmanship?}

It has been and remains difficult to predict the outcome of the Danish chairmanship. Much of the early Danish debate focused on reforming the Convention system. Later, focus shifted to the Court's dynamic interpretation. More recently, however, the Government seems to have changed tack. Whereas blame was initially placed squarely with the European Court of Human Rights, the Danish Prime Minster has since acknowledged that Danish courts might have wrongly applied human rights precedents. ${ }^{16}$ This shift of blame seems to have lowered expectations of the chairmanship and the

12 Dean Spielmann, "Whither Judicial Dialogue?", Sir Thomas More Lecture, Lincoln's

Inn (12 October 2015).

13 Conference report (n 7) 5.

14 By comparison, in 2016 Denmark intervened in 34 EU cases before the European Court of Justice.

15 This possibility will not be open to the Danish Supreme Court unless Denmark ratifies protocol 16.

16 See press conference (n 11). 
Danish Government now seems to be focused on a stocktaking exercise that will result in the adoption of a political declaration in April 2018. But whilst the Convention system and Article 8 appears to be safe-at least for the time being - there seems little prospect of an end to the populist agenda, which is spurred on by a significant political segment in Denmark that continues to want and demand reform to the Convention. 